\title{
Evaluation of the performance of tuberculosis control actions and services of the family health strategies
}

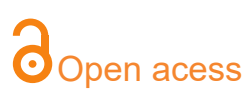

${ }^{1}$ Sanitary Physiotherapist by the School of Government in Public Health of the State of Pernambuco, Master's Degree in Health Sciences by ABC Medical School, Santo André, SP, Brazil

${ }^{2}$ Commission for Postgraduate, Research and Innovation. Postgraduate Program in Health Sciences. Faculty of Medicine of ABC, Santo André, SP, Brazil

${ }^{3}$ School of Sciences of Santa Casa de Misericórdia de Vitória (EMESCAM), Laboratory of Scientific Writing - Nursing.

${ }^{4}$ Department of Pharmaceutical Sciences, Federal University of São Paulo, UNIFESP, Diadema, SP. Laboratory of Clinical Analysis, ABC Medical School, Santo André, SP, Brazil.

${ }^{5}$ Federal University of the Valley of the São Francisco - Collegiate of Medicine, Petrolina, Pe, Brazil. Laboratory of Study Design and Scientific Writing, ABC Medical School, Santo André, SP, Brazil

\section{Corresponding author:}

Manuscript received: April 2018

Manuscript accepted: October 2018

Version of record online: November 2018
Fábia Maria de Santana ${ }^{1,2}$, Ana Paula de Araújo Machado ${ }^{3}$, Patrícia Poleto Monhol $^{3}$, Ligia Ajaime Azzalis ${ }^{4}$, Virginia B. C. Junqueira ${ }^{4}$, David Feder $^{4}$, Leela Morená ${ }^{5}$, Fernando Luiz Affonso Fonseca ${ }^{2,4}$

\begin{abstract}
Introduction: Front of the persistence of tuberculosis in several municipalities in the country, the Ministry of Health (MS) established the National Tuberculosis Control Plan (NTCP), whose goals were to integrate $100 \%$ of the Brazilian municipalities in the fight against the disease.
\end{abstract}

Objective: To evaluate the performance of tuberculosis (TB) control actions and services of the Family Health Strategies in the city of Salgueiro-PE.

Method: Cross-sectional, quantitative and descriptive survey study that evaluated health services in the city of Salgueiro$\mathrm{Pe}$, involving 40 participants. The data were selected through the steps of specific questions for the evaluation of TB, in addition to the questions on the epidemiological situation and the current state of health. In order to know the conditions for the control of TB in the municipality, a script was also elaborated with orientations directed to the manager.

Results: The results of our study showed a population aged from 34 to 59 years with a predominance of males (70\%) and incomplete elementary school $(37.5 \%)$. Regarding the place of diagnosis, the hospital had a higher prevalence of cases diagnosed with tuberculosis with $62.5 \% .85,0 \%$ performed the Directly Observed Treatment. The averages of the evaluated actions showed that the municipality of Salgueiro-PE does not develop actions of health education and active search of symptomatic respiratory patients, The results were favorable only for the accomplishment of sputum bacilloscopy, monthly consultations of control and medical monitoring.

Conclusion: The results showed weaknesses in the performance of actions and services by the Family Health Strategy in the municipality of Salgueiro, with damage to TB control and treatment

Keywords: Tuberculosis, primary health care, evaluation of health services. 


\section{INTRODUCTION}

Basic care is the result of the development and consolidation of the Health Unic System (HUS) through the Family Health Strategy (FHS) program. Created in 1994, the FHS covered $63 \%$ of the Brazilian population in 2015 and has been associated with the reduction in infant mortality and the number of preventable hospitalizations ${ }^{1}$. Basic care is the result of the development and consolidation of Unified Health System (UHS) through the Family Health Strategy (FHS) program. A study conducted in BeloHorizonte-MG with a sample of 7,778 adults, showed that individuals attended by the FHT had a better performance in health usage when compared to non-SUS users. In this context, the Family Health Strategy has been an important tool in the management of diseases prevalent in national epidemiology, such as tuberculosis (TB) ${ }^{2}$.

TB is an infectious disease, considered a public health problem, punctuating with high magnitude, transcendence and vulnerability in the criteria for disease selection and priority aggravations to epidemiological surveillance ${ }^{3}$.

In 1993, the WHO declared a state of emergency against TB. As a reflection, Brazil developed strategies within the FHS signaling its position through the creation of the Emergency Plan for Tuberculosis Control, the first strategy of the Ministry of Health in the fight against tuberculosis ${ }^{4}$. In a short time another strategy was defined, the National Policy for the Control of Tuberculosis (NPCT), resulting from the need to increase considerations about the tuberculosis problem, with a view to making interventions in the health system in Brazil and on the possible contributions that the incorporation of new technologies may lead to on the disease surveillance system $^{5}$.

The NPCT understands TB treatment as a responsibility of all HUS services and recognizes the need to integrate basic care, including programs of community agents and family health, aiming at greater access to the management of this disease. Therefore, basic care is structured as the first point of attention and the main entry point of the system, consisting of a multidisciplinary team that covers the entire population, integrating, coordinating care and attending to their health needs. Decree No. 7,508, of July 28, 2011, which is regulated by Law No. 8,080 / 90, defines that "universal, equal and orderly access to health actions and services starts at the entrance door of the HUS and it is completed in the regionalized and hierarchical network"

Among the activities performed by primary care, besides the diagnosis and treatment of TB are: active search for respiratory symptoms (people with cough and expectoration for more than 3 weeks), supervising the control of contacts of patients with bacilli in the community, notifying the Information System called SINAN, follow-up of the cases under treatment, ensuring the performance of the diagnostic tests, participating in the operationalization of the treatment directly observed in the municipality, and following the prophylactic control measures ${ }^{7}$.
The definition of TB as a priority in the public health agenda at local level runs through operational and political obstacles, such as the distribution of resources prioritizing other situations such as urgency / emergency and dengue care. There is a gap in the financing policy for TB and a municipal management pattern that is not very committed to disease control, and the manager's involvement in incorporating, investing and supporting the management of TB control actions is fundamental, assuming the disease as a priority in the municipal health agenda ${ }^{8}$.

Thus, the purpose of this manuscript is to analyze the performance of tuberculosis control actions and services of the Family Health Strategy.

\section{METHODS}

\section{Type of study}

Descriptive survey study for the evaluation of health services, of a quantitative nature and cross-sectional character.

\section{Sample selection process}

The research used the structure of the 18 Family Health Strategies (FHS) of the municipality of Salgueiro$\mathrm{PE}$ to locate the addresses of TB patients. Data were collected at the homes of each patient who had or was still under TB treatment, through the participant researcher with the community health agents (CHA). During the collection period, some elements were facilitators and others obstacles to this process (Table 1).

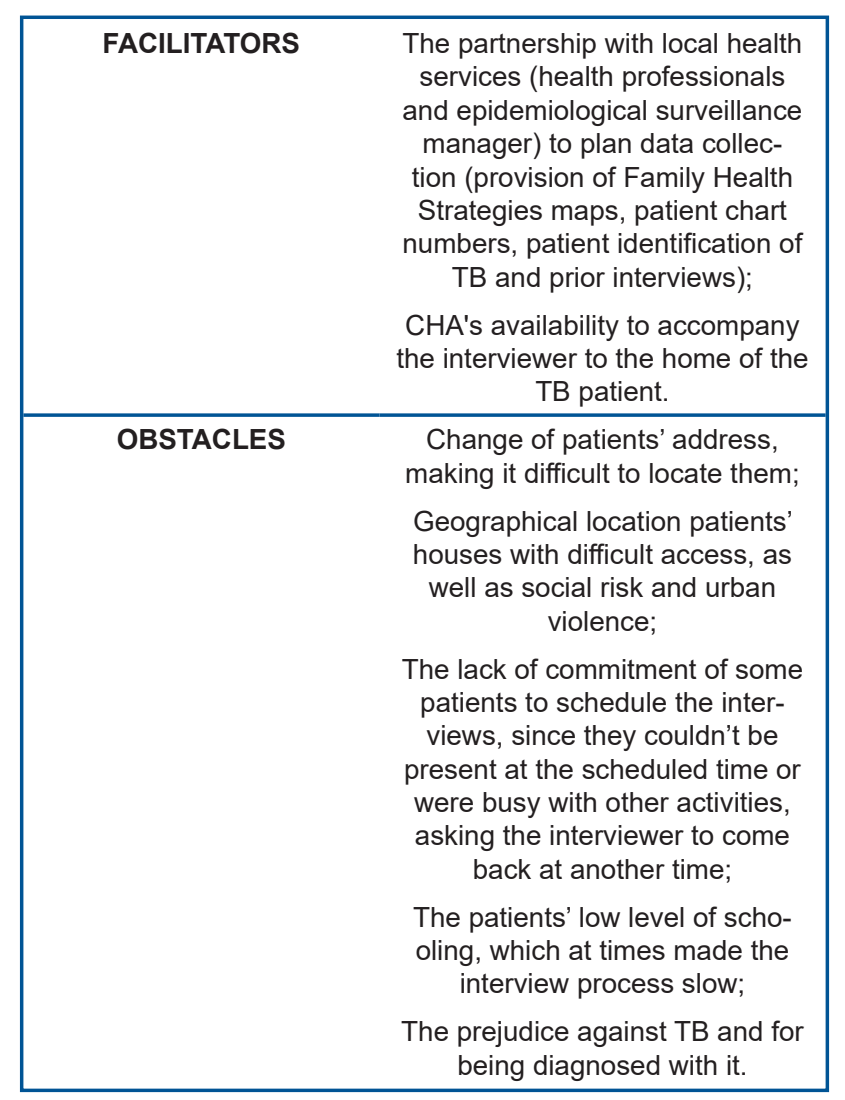

Chart 1: Facilitators and obstacles in the data collection process. 
The study followed the principles normalized by the National Health Council (CNS), by resolution n. 466, December 2012, taking into consideration the ethical aspects that regulate the research involving human beings

All the patients selected read or were informed about the free and clarify consent term (FCCT), approved by the ethics and research committee of the ABC Medical School (opinion no. 1,893,761).

\section{Participants}

To select the sample of the research, an analysis was carried out together with the epidemiological surveillance to identify the number of cases described in the registry book and follow-up of the treatment of patients with tuberculosis from January 2014 to September 2016. A population of 84 TB patients enrolled in the family health strategy was obtained. The following criteria were used as inclusion criterion: age 18 years or older, having good cognition, living in the city of Salgueiro / PE, who performed or performed the treatment at FHS and consent to the study by signing the FCCT. Exclusion Criteria: TB patients who are in the prison system.

\section{Data collection instrument}

The research data were collected through a questionnaire developed for TB patients from the Primary Care Assessment $\mathrm{Tool}^{9}$, validated and adapted for $\mathrm{TB}$ attention ${ }^{10}$. The instrument contains 86 specific questions for each essential organizational component of basic care for TB control actions, as well as questions on patient profile, clinical epidemiological information and current health status.

The Likert scale was used to evaluate the level of agreement in opinion polls. A value of 0 to 5 was assigned. "Zero" identified the "do not know or do not apply" response and values from 1 to 5 record the degree of preference (or agreement) relationship of the statements.

To better identify which policies exist in the municipality of Salgueiro-PE for TB control, an interview script was developed for the main actor (manager) involved in the reorganization process of health services.

\section{Statistical analysis}

Absolute and relative values were used to describe the characteristics of the qualitative variables for the quantitative variables, median and percentiles. A confidence level of $95 \%$ was used for all analyzes and the statistical program used was the Data Analysis and Statistical Software for Professionals (Stata) version 11.0®. After obtaining the averages, these were related to the Likert scale.

The main aspects and variables analyzed were:

- Regarding the sociodemographic character: Sex, age, and schooling

- Regarding health education: conducting health education on subjects other than TB, Participation of TB patients in groups in health services, Educational work carried out by health professionals in the community.

- Regarding medication control: Access to medical care if malaise due to medication, the absence of medication during treatment for TB

- Regarding the previous diagnosis and follow-up in the treatment of TB: Offer by the health services of the recipients for monthly sputum examination; Visit of health professionals to deliver the recipients for sputum collection; Actions with churches, neighborhood associations, for delivery of the recipients for sputum collection; Performing the skin test by the health services; Monthly consultation offered by health services.

\section{RESULTS}

Of the 84 registered cases of tuberculosis, 16 $(19 \%)$ of the patients moved to another municipality, $49(58 \%)$ with discharge for cure, $5(6 \%)$ in the prison system, 3 (4\%) with changes on diagnosis, 2 (2\%) TB with associated diseases such as pneumonia and pleural effusion, 1 (1\%) TB + HIV, $5(6 \%)$ deaths and $3(4 \%)$ wanderers (without fixed residence). Thus, the sample studied consisted of 40 patients. Figure 1, below, presents the process of locating tuberculosis cases (Figure 1).

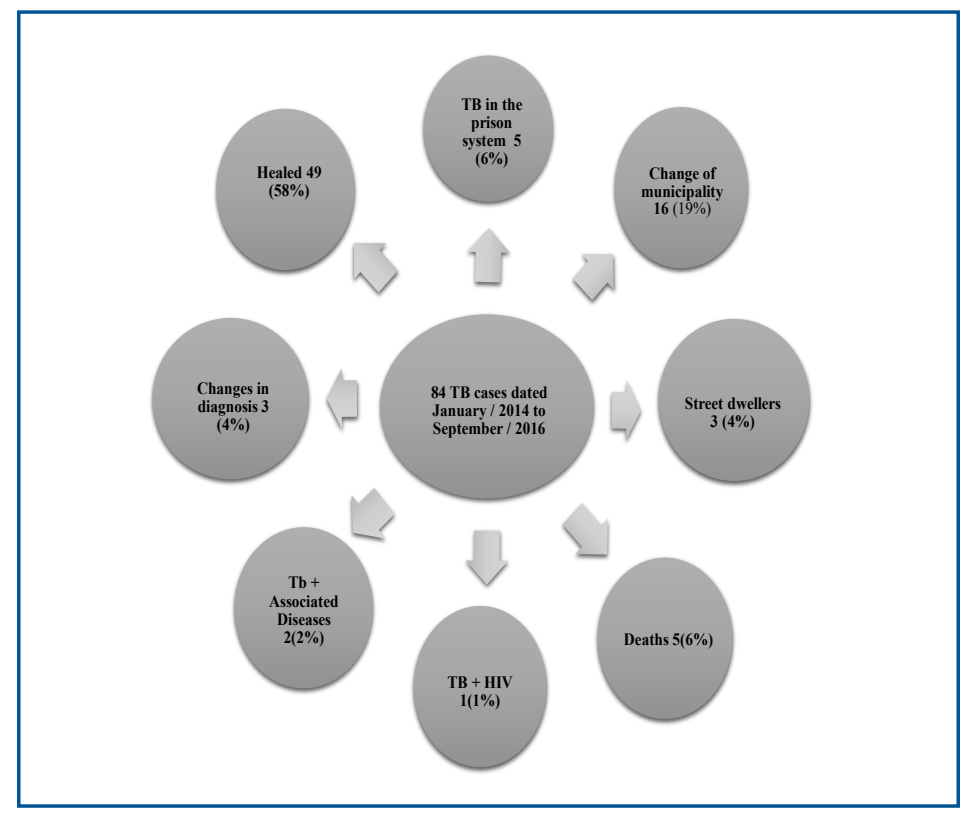

Figure 1: Epidemiological distribution of TB cases. 


\section{DISCUSSION}

The incidence rate of TB in Brazil is high ${ }^{12,13}$. In 2013, Brazil registered 71,123 new cases of tuberculosis, equivalent to an incidence rate of 35.4 cases per 100,000 inhabitant which indicates a decrease of $20.3 \%$ in relation to 2003 when the rate was 44.4 cases per 100 thousand people. Also, in 2013, 4,406 deaths per TB were reported at a rate of 23 deaths per 100,000 inhabitants. Brazil ranks the 16th place among the 22 countries with the highest TB prevalence and 111th in terms of incidence rates. According to the Ministry of Health, in 2011 were estimated 9 million new cases of the disease in the world, in addition to 1.4 million deaths ${ }^{14,12}$.

In Pernambuco, there is an average of 4,230 new cases of tuberculosis per year. The State presented the 4th place in disease detection rate and 2nd place in mortality in the country and 1 st place in number of cases in the Northeast in 2010, being Recife the Brazilian capital with the highest incidence rate $(48.2 \%)$, and one of the municipalities that make up the I Regional Health Administration (I GERES), which holds $70 \%$ of tuberculosis cases among the 12 GERES of the state ${ }^{15}$.

In Brazil, the number of tuberculosis cases in males is twice the number of females, around 50 per 100,000 inhabitants ${ }^{11}$. In this study, the socio-demographic characteristic revealed that of the $40 \mathrm{~TB}$ patients, there was a predominance of males with $70 \%$ (28), compacting with national information ${ }^{16}$. This trend may be related to the greater exposure of men outside the home and also because, culturally, men resort less to health services ${ }^{17}$.

The sociodemographic characterization of the eligible participate sample (40 patients) was predominantly male $(70 \%), 30 \%$ (12) had incomplete primary education and $37.5 \%$ (15) were between the ages of 34 to 59 years of age (table 1).
When asked about the primary diagnosis site, the hospital environment had a higher prevalence of diagnosed cases with tuberculosis with $62.5 \%$ (25) versus $37.5 \%$ (15) of diagnoses within the FHS.

Participants were also questioned about directly observed treatment (DOT), a strategy established by the National Tuberculosis Control Program (NTCP) to regulate and enable the quality of TB patient care, with the primary action being the supervision of medication, made by a professional or person properly qualified for this purpose, and it should be performed in any environment, which is more comfortable for the user ${ }^{11,10}$. The DOT helps reduce the possibility of drug resistance, withdrawal from treatment and encouraging adherence to therapy.

Among the TB patients interviewed, 85.0\% (34) performed the DOT, with only $15.0 \%$ (6) who did not (Figure 2). Regarding the place of care, 27.5\% (11) performed the supervised treatment at the FHS and $72.5 \%$ (29) at home.

About the relation to the variables: "health education activity on subjects other than TB", "participation of TB patients in groups in the health services", Table 2 shows a non-favorable average indicating that the largest number of patients reported do not perform any of the activities. However, the variable "Educational work carried out by health professionals in the community" obtained an average of $45 \%$, indicating a regular level (table 2 ).

The results found for the variables: "access to medical care within 24 hours when an incident caused by the use of medication happens", obtained a regular average indicating that the study patients commonly have access to the health service. The data collected on a Likert scale for "lack of medication" obtained an average of $100 \%$ for the "almost never" response, presenting a favorable level, that is, almost never missing medication (Table 3).

Table 1: Socio-demographic characterization of the studied population, Salgueiro-Pe,2017

\begin{tabular}{lcc}
\hline Variables & $\mathbf{n}$ & \% \\
\hline Sex & & 70.0 \\
Male & 28 & 30.0 \\
Female & 12 & \\
SCHOLARITY & & 27.5 \\
Whitout schooling & 11 & 37.5 \\
Incomplete elementary school & 15 & 20.0 \\
Complete elementaray school & 8 & 12.5 \\
Incomplete secondary school & 5 & 2.5 \\
Complete secondary school & 1 & \\
& & p.25-p.75 \\
Age & Mediana & $34.0-59.5$ \\
\hline
\end{tabular}

p.25 - p.75: percentil 25 e 75 


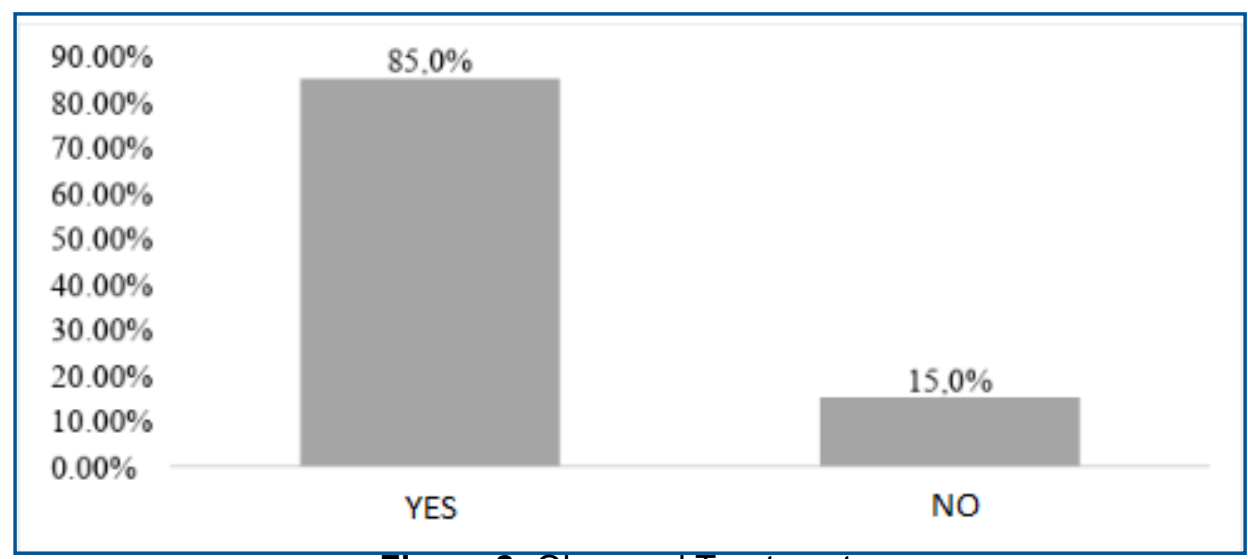

Figure 2: Observed Treatment

Table 2: Evaluation of the item "Health education" by Likert scale, Salgueiro-Pe, 2017

\begin{tabular}{lcc}
\hline Variables & $\mathbf{n}$ & $\mathbf{\%}$ \\
\hline Realization of health education about other topics besides TB? & & \\
ALMOST NEVER & 8 & 20.0 \\
ALMOST ALWAYS & 10 & 25.0 \\
NA & 22 & 55.0 \\
Participation of TB patients in groups in health services? & & \\
ALMOST NEVER & 40 & 100 \\
Educational work done by health professionals in the community? & 7 & 17.5 \\
ALMOST NEVER & 15 & 37.5 \\
ALMOST ALWAYS & 18 & 45.0 \\
ALWAYS & & \\
\hline
\end{tabular}

Table 3: Evaluation of the item "Access to the Health Service" by Likert scale, Salgueiro-Pe, 2017

\begin{tabular}{lcc}
\hline Variables & $\mathbf{n}$ & $\%$ \\
\hline If you feel sick because of the medication you get a doctor's appointment within 24 hours? & & \\
SOMETIMES & 2 & 5.0 \\
ALMOST ALWAYS & 7 & 17.5 \\
ALWAYS & 17 & 42.5 \\
NA & 14 & 35.0 \\
Is there a lack of medication during treatment for TB? & & \\
ALMOST NEVER & 40 & 100 \\
\hline
\end{tabular}

The mean reached in the four variables: "offer by the health services of the recipients for diagnosis of TB"; "Offer by the health services of the recipients for monthly sputum examination"; "Monthly consultation offered by health services"; "Visits by health professionals to deliver the recipients for sputum collection", in the services of the FHS were favorable, that is, the recipients were always offered for diagnosis and examination as well as monthly consultation of control and visit of health professionals were done.

However, the results were not favorable in the variables " skin test performed by the health services"; "Service actions with churches, neighborhood associations, for delivery of recipients for sputum collection", that is, these activities are never performed by FHS.

\section{Sociodemographic Characterization}

About schooling, the study showed a higher frequency among patients with incomplete primary education, $37.5 \%$ (15) of the sample. In a research performed in Rio de Janeiro, referring to the distribution of monthly consultations of tuberculosis according to demographic and clinical variables of the users, almost $40 \%$ corresponded to individuals without schooling or incomplete elementary education ${ }^{18}$.

According to Lindoso et al..$^{19}$ and Santos et al. ${ }^{20}$, people with low educational level have a lower adherence to TB treatment, because they have an erroneous perception of the disease and do not seek health services, regarding the diagnosis and treatment, and increasing the abandonment number ${ }^{19,20}$.

The interviewees under study were within the economically active age group, between 34 to 59 years of age. These data corroborate with a study conducted by Ferrer et al. ${ }^{21}$. in Santa Catarina, where the highest rates found were in the age groups of 30-44 and 45-59 years and with a study carried out in the city of Teresina-PI. In this study, the incidence was between the age group older 
than 50 years $^{21,22}$.

Regarding the diagnosis site, the hospital had a higher prevalence of cases diagnosed with tuberculosis with $62.5 \%$, as presented in surveys carried out by Silva Sobrinho 23 and Ponters et al. ${ }^{24}$, where this reality reflects a reversal of the flow of treatment and diagnosis of tuberculosis, since primary health care is recommended as a preferential gateway to the HUS. Thus, its noted the difficulty of the basic network in identifying and meeting the needs of the community, which causes overcrowding of the emergency sector with problems that could be solved in other levels of attention ${ }^{23,24}$.

\section{Directly Observed Treatment}

The Ministry of Health, together with the NTCP, makes control of the primary drug treatment in the fight against tuberculosis, having as one of the pillars of the DOT, the distribution of the medication in the intention to have a better control in the use of the drugs used in Brazil $^{19}$.

Discontinuation of therapy is one of the major obstacles to TB cure and it is considered a multifactorial problem. According to a study by Chirinos et al. ${ }^{25}$, the sociodemographic factors are the ones that are most related to this abandonment, so it is recommended that this team has effective and vigilant control over drug therapy ${ }^{26}$. For Souza et al. ${ }^{26}$.the greatest difficulties in TB control are the delay in seeking the health service due to the fear of diagnosis, as well as the fear of discrimination by society, therefore it is necessary that users are familiarized with the health team of FHS.

Among the TB patients interviewed, 85\% performed supervised treatment and only $15 \%$ did not participate in the DOT. Regarding the place of care, $27.5 \%$ had supervised treatment at the FHS and $72.5 \%$ at home. Research carried out in several municipalities in the country shows that primary care effectively performs the DOT, but still can not reach a total of $100 \%$ of patients ${ }^{4}$.

\section{Health education}

The variables "health education activity on subjects besides TB”, "TB patients participation in health services groups", obtained a non-favorable result, indicating that they did not perform any of these activities. However, the variable "Educational work carried out by health professionals in the community" obtained an average of $45 \%$ indicating a regular level. These data reveal the conception of the health-disease process is still very closely linked to the clinic itself, showing a discrepancy with what is proposed by the principles and guidelines of the HUS, which has health education as a basis for health promotion $^{27-30}$.

In addition, the study shows that the service evaluated does not develop health education actions in TB control, especially in the indicator "patient participation in groups", even though these actions are considered by the Ministry of Health and recommended in the NTCP as a primary strategy control and adherence to TB treatment.

Health education should be developed through organized and teamwork, being used as a strategy for TB control, developing patient empowerment, and promoting dialogue between health professionals and users, citizen autonomy and the encouragement of an active posture of these subjects in their political and social environments, developing opportunities to enlarge the understanding of the problems and to reflect on the intervention about the reality in which they live, privileging the promotion of their autonomy ${ }^{31,32}$.

Teamwork was codified by the group as the primary point for the performance of the family health strategy. During the decoding/problematization, the major contributions of the subjects were shown through the perspective that the common goal of care and health promotion of the population can only be achieved through teamwork.

A study by Sá et $a l .^{31}$ corroborates our findings, where health education practices are incipient and not very expressive in the work process of primary health care professionals ${ }^{26}$.

One of the strategies considered a priority by the NTCP is predicted to increase case detection in different socioeconomic and clinical epidemiological scenarios by strengthening the primary health care (PHC) service system. It is extremely important that the family health team acts in the surveillance, prevention and control of the disease ${ }^{33-35}$.

\section{Access to Health Service}

The results found in this study show that medical care within 24 hours was regular, indicating access to the health service. This aspect diminishes the incidence of treatment abandonment of tuberculosis since health professionals are accessible to guide, evaluate and monitor the health status of the TB carrier. According toSantos et $a l .{ }^{20}$ and Rodrigues et $a l .{ }^{34}$, the perception of the relations with the health service and the institutional field can be factors that contribute or not to the abandonment of the treatment, since the side effects presented by the patients can cause extra consultations to treat the complaints ${ }^{20,35}$.

The data about "lack of medication" averaged $100 \%$, presenting a favorable level, that is, never or almost never missing medication. The delivery of the medication is exclusive to the health services, as they can not be sold in pharmacies, and the misuse of medication is one of the risk factors for the patient to become resistant to the drug, because of this, the treatment can't be interrupted. The NTCP, when refers to TB control, is primarily aimed at breaking the chain of transmission and the main means to achieve this goal is to perform the diagnosis and early treatment so that bacilli are not disseminated, with the outcome of curing the disease $\mathrm{e}^{11,13}$.

A study conducted by Lafaiete et $a{ }^{35}$ indicate that the results are favorable with medical care within 24 hours, with access to drugs for the treatment of TB. This fact reveals an adequate planning and distribution of drugs by the team that coordinates the treatment control program in the municipality, as they include essential steps in the selection, procurement, distribution and appropriate use of the drug.

\section{Diagnosis}

Bacilloscopy is used in public health to confirm the 
diagnosis of TB since it is a simple and safe technique, it has two important purposes in TB control: detection of bacilliferous cases, responsible for the chain of transmission, and control of treatment and efficacy. For this reason, it is recommended that in all TB diagnoses a bacilloscopy for confirmation be requested and that it be performed every month, that the communicants and other citizens perform the skin test (PST), for an early diagnosis ${ }^{11,36}$.

The follow-up of TB treatment was evaluated through periodic sputum controls in the variables: "offer by the health services of the recipients to diagnose TB"; "Offer by recipients health services for monthly sputum examination"; "Monthly consultation offered by health services"; "Visits by health professionals to deliver the recipients for sputum collection". The results showed that such monitoring has been a priority in the city of Salgueiro, presenting favorable percentage levels (table 4). Corroborating with a study carried out by Lima et al..$^{37}$, who presented positive results regarding the performance of follow-up smear microscopy.

Table 4: Evaluation of the "Diagnosis and Control" question by Likert scale, Salgueiro-Pe, 2017

\begin{tabular}{lll}
\hline Variables & $\mathbf{n}$ & $\%$ \\
\hline
\end{tabular}

Is there offer by health services from the recipients for diagnosis of TB?

ALWAYS

Is there offer by health services from the recipients for monthly sputum examination?

ALWAYS

Is there monthly consultation offered by health services?

ALWAYS

Does the skin test performed by the health services happen?

ALMOST NEVER

Are there actions with churches, neighborhood associations, to deliver recipients for sputum collection?

ALMOST NEVER

Do health-care provider visits for delivery of the sputum collection recipients?

\section{ALWAYS}

Control actions such as "perform the skin test by the health services" and "actions with churches, neighborhood associations, to deliver the recipient for sputum collection", have had unfavorable results, which determines that the municipality has not met all the goals of the NTCP, which has only been conducting clinical actions, and regarding promotion and prevention actions, such as active search and exams for early diagnosis, such as PST, has not performed them in the municipality under study. These data are corroborated with studies carried out by Oliveira ${ }^{38}$ in Ribeirão Preto - SP, showing the same profile where the diagnostic bacilloscopy is performed, but the active search is not done.

The supply of recipients for sputum examination in the community and the PST, has been the priority action in the active search for respiratory symptoms, becoming part of the routine of services and mainly primary health care, in order to obtain the early detection of cases of TB. Having as an instrument of work the family and the home, the FHS has a privileged space for these actions ${ }^{39,40}$.

\section{Repercussions in the Field of Public Health}

In relation to the TB control policy established in the city of Salgueiro, health education and the active search for respiratory symptomatology, in the variables "Participation of TB patients in groups in health services", "actions with churches, neighborhood associations, for delivery of recipients for sputum collection ", did not obtain favorable averages, that is, the municipality does not perform these activities, and can be justified as shown by Silva et $a l .{ }^{41}$ research to the inexistence of a policy of permanent education, consistent with the existing epidemiological situation and the turnover of health professionals is related to the political-partisan discontinuity in the municipality, which may hinder the maintenance of qualified health teams to deal with TB in primary care services.

In this way, it is important to highlight the study conducted by Queiroz et $a l .{ }^{42}$ and Terra et $a l .{ }^{43}$ on the identification of problems related to therapeutic adherence and TB control, in which they highlighted that issues related to the qualification of the teams need to reach a greater discussion and execution, since most of the professionals who work in primary care have already experienced the training process centered on the curativist model and not on health promotion.

For Samico et al. ${ }^{44}$, health evaluation has become an effective alternative to provide answers regarding planned and executed actions, providing information on the way health systems users function, quality, effectiveness, safety and satisfaction. Thus, this study allowed the verification of actions, such as health education and the active search for respiratory symptomatic patients, which, even if it did not occur, the manager reported being executed. This leads to the generation of information that will give managers and health professionals the need to reflect and intervene in these indicators to modify the epidemiological picture presented by the disease, indicating the need for research and research that produce positive results in the disease process and improvement of the population's health ${ }^{45,46}$. 
It is observed that TB patients are mostly young adults with low schooling and males, which generates a social-economic problem for families, since the disease often leaves this group unable to work, taking from the provider the condition of livelihood.

Although the municipality has favorable conditions to carry out tuberculosis control actions in primary care, it is possible to detect a large concentration of diagnoses identified by the hospital's network, causing a reversal of the flow of care and diagnosis of tuberculosis. There was a satisfactory performance in relation to the activities related to the offer of treatment actions, such as medical care, bacilloscopy, and medications. As a result of the non-execution of some health indicators such as an active search for respiratory symptomatic and health education, TB control actions remain at a favorable, non-favorable and regular level, which determines that there is no linearity in TB control actions in the FHS.

Therefore, the findings of this study point to the need to implement policies aimed at health education and active search for respiratory symptomatic patients, with actions directed not only at the sick but also at the family and community levels. For this, the commitment of the management in the actions established in the control of TB in the municipality, as well as the health professionals and the population involved, must know its real assignments, in order to fulfill the goals suggested by the World Health Organization (WHO) and $\mathrm{MH}$ in the fight against the disease.

\section{CONCLUSION}

The evaluation of the performance of tuberculosis control actions and services of the family health strategy in the city of Salgueiro-PE pointed to weaknesses in the diagnosis of TB, as seen in the flow of care and diagnosis of tuberculosis, absence in the actions of health education and search active respiratory symptomatic, which end up causing damage to the control and treatment of tuberculosis.

\section{REFERENCES}

1. Andrade MV, Coelho AQ, Xavier Neto M, Carvalho LR, Atun R, Castro MC. Brazil's Family Health Strategy: factors associated with programme uptake and coverage expansion over 15 years (19982012). Health Policy Plan. 2018;33(3):368-80. DOI: http://dx.doi.org/10.1093/heapol/czx189

2. Lima-Costa MF, Turci MA, Macinko J. Estratégia Saúde da Família em comparação a outras fontes de atenção: indicadores de uso e qualidade dos serviços de saúde em Belo Horizonte, Minas Gerais, Brasil. Cadernos de Saúde Pública, 2013;29(7):1370-80. DOI: http://dx.doi.org/10.1590/S0102-311X2013000700011

3. Lacerda SNB, Temoteo RCA, Figueiredo TMRM, Luna FDT, Sousa MAN, Abreu LC, et al. Individual and social vulnerabilities upon acquiring tuberculosis: a literature systematic review. Int Arch Med. 2014;7:35. DOI: http://dx.doi.org/10.1186/1755-7682-7-35

4. Hijjar MA, Gerhardt G, Teixeira GM, Procopio MJ. Retrospecto do controle da tuberculose no Brasil. Rev Saúde Pública. 2007;41(Suppl.1):50-7. DOI: http://dx.doi.org/10.1590/S0034-89102007000800008

5. Souza WV, Albuquerque MFM, Barcellos CC, Ximenes RAA, Carvalho MS. Tuberculose no Brasil: construção de um sistema de vigilância de base territorial. Rev Saúde Pública. 2005;39(1):82-9. DOI: http://dx.doi.org/10.1590/S0034-89102005000100011

6. Brasil. Ministério da Saúde. Secretaria de Atenção à Saúde. Departamento de Atenção Básica. Política Nacional de Atenção Básica. Brasília: Ministério da Saúde, 2012.

7. Brasil. Ministério da Saúde. Secretaria de Vigilância em Saúde. Departamento de Vigilância das Doenças Transmissíveis. Experiências de monitoramento e avaliação no controle da tuberculose no Brasil. Brasília: Ministério de Saúde, 2013.

8. Santos MLSG, Villa TCS, Vendramini SHF, Gonzáles RIC, Palha PF, Santos NSGM, et al. A gerência das ações de controle da tuberculose em municípios prioritários do interior paulista. Texto Contexto Enferm. 2010;19(1):64-9. DOI: http://dx.doi.org/10.1590/S0104-07072010000100007

9. Almeida C, Macinko J. Validação de uma metodologia rápida das características organizacionais e do desempenho dos serviços de atenção básica do Sistema Único de Saúde (SUS) em nível local. Brasília: Organização Pan-Americana de Saúde, 2006.

10. Ruffino-Neto A, Villa TCS. Tuberculose: pesquisas operacionais. São Paulo: FUNPEC, 2010.

11. Brasil. Ministério da Saúde. Secretaria de Vigilância em Saúde Departamento de Vigilância Epidemiológica. Doenças infecciosas e parasitárias: guia de bolso. Brasília: Ministério da Saúde, 2010.

12. Brasil. Ministério da Saúde. Secretaria de Atenção à Saúde. Departamento de Atenção Básica. Vigilância em Saúde: Dengue, Esquistossomose, Hanseníase, Malária, Tracoma e Tuberculose. Brasília: Ministério da Saúde, 2008.

13. Micheletti VCD, Bordin R. Programa de controle da tuberculose da secretaria municipal de saúde de Porto Alegre: Adesão ao tratamento a partir da análise das estratégias da equipe de saúde. Monografia (Conclusão de Curso) - Universidade Federal do Rio Grande do Sul. Porto Alegre: 2008. 
14. Brasil. Instituto Brasileiro de Geografia e Estatística (IBGE). Cidades, 2013. [cited 2016 Sep 12] Available from: http://cidades.ibge.gov.br/xtras/perfil.php?lang=\&codmun=230180.

15. Pernambuco. Secretaria Estadual de Saúde. Secretaria Executiva de Vigilância em Saúde. Programa de Enfretamento das Doenças Negligenciadas no Estado de Pernambuco: SANAR: 2011-2014. Recife: Secretaria Estadual de Saúde, 2013.

16. Vieira AN, Fernandes ACL, Lima DWC, Oliveira WS, Lima LCS, Oliveira LKS. Casos de Tuberculose Notificados no SINAN. Rev Baiana Saúde Pública. 2013;37(4):869-80.

17. Gosoniu GD, Ganapathy S, Kemp J, Auer C, Somma D, Karim F, et al. Gender and socio-cultural determinants of delay to diagnosis of TB in Bangladesh, India and Malawi. Int J Tuberc Lung Dis. 2008;12(7);848-55.

18. Portela MC, Lima SML, Brito C, Ferreira VMB, Escosteguy CC, Vasconcellos MTL. Programa de Controle da Tuberculose e satisfação dos usuários, Rio de Janeiro. Rev Saúde Pública. 2014;48(3):497507. DOI: http://dx.doi.org/10.1590/S0034-8910.2014048004793

19. Lindoso AABP, Waldman EA, Komatsu NK, Figueiredo SM, Taniguchi M, Rodrigues LC. Perfil de pacientes que evoluem para óbito por tuberculose no município de São Paulo, 2002. Rev Saúde Pública. 2008;42(5):805-812. DOI: http://dx.doi.org/10.1590/S0034-89102008000500004

20. Santos MLSG, Vendramini SHF, Gazetta CE, Oliveira SAC, Villa TCSV. Pobreza: caracterização socioeconômica da tuberculose. Rev Latino-Am Enfermagem. 2007;15(esp). DOI: http://dx.doi.org/10.1590/S0104-11692007000700008

21. Ferrer GCN, Silva RM, Ferrer KT, Traebert J. A carga de doença por tuberculose no estado de Santa Catarina. J Bras Pneumol. 2014;39(6):61-8. DOI: http://dx.doi.org/10.1590/S1806-37132014000100009

22. Coelho DMM, Viana RL, Madeira CA, Ferreira LOC, Campelo V. Perfil epidemiológico da tuberculose no Município de Teresina-PI, no período de 1999 a 2005. Epidemiol Serv Saúde. 2010;19(1):33-42.

23. Silva-Sobrinho RA, Andrade RLP, Ponce MAZ, Wysocki AD, Brunello ME, Scatena LM, et al. Retardo no diagnóstico da tuberculose em município da tríplice fronteira Brasil, Paraguai e Argentina. Rev Panam Salud Publica. 2012;31(6):461-8.

24. Pontes APM, Cesso RGD, Oliveira DC, Gomes AMT. Facilidades de acesso reveladas pelos usuários do sistema único de saúde. Rev Bras Enferm. 2010;63(4):574-80.

DOI: http://dx.doi.org/10.1590/S0034-71672010000400012

25. Chirinos NEC, Meirelles BHS. Fatores associados ao abandono do tratamento da tuberculose: uma revisão integrativa. Texto Contexto Enferm. 2011;20(3):599-606.

26. Souza EP, Barbosa ECS, Rodrigues ILA, Nogueira LMV. Prevenção e controle da tuberculose: revisão integrativa da literatura. Rev Cuid. 2015;6(2):1094-102. DOI: http://dx.doi.org/10.15649/cuidarte.v6i2.178

27. Arakawa T, Villa TCS, Arcêncio RA, Cardozo-Gonzales RI, Scatena LM, Ruffino-Netto A. A acessibilidade de doentes de tuberculose ao tratamento em serviços de saúde no munícipio de Ribeirão Preto- São Paulo (2006-2007). In: Villa TCS, Ruffino Netto A. Tuberculose: pesquisas operacionais. Ribeirão Preto: FUNPEC, 2009; p. 48-55.

28. Jesus MCP, Santos SMR, Amaral AMM, Costa DMN, Aguilar KSM. O discurso do enfermeiro sobre a prática educativa no programa saúde da família em Juiz de Fora, Minas Gerais, Brasil. Rev APS. 2008;11(1):54-61.

29. Bezerra IMP, Sorpreso ICE. Concepts and movements in health promotion to guide educational practices. J Hum Growth Dev. 2016;26(1):11-20. DOI: https://doi.org/10.7322/jhgd.113709

30. Fernandes MCP, Backes VMS. Educação em saúde: perspectivas de uma equipe da Estratégia de Saúde da Família sob a ótica de Paulo Freire. Rev. Bras Enferm. 2010;63(4): 567-73. DOI: http://dx.doi.org/10.1590/S0034-71672010000400011

31. Sá LD, Gomes ALC, Carmo JB, Souza KMJ, Palha PF, Alves RS, et al. Educação em saúde no controle da tuberculose: perspectiva de profissionais da estratégia Saúde da Família. Rev Eletr Enf. 2013;15(1):103-11. DOI: http://dx.doi.org/10.5216/ree.v15i1.15246

32. Clementino FS, Marcolino EC, Gomes LB, Guerreiro JV, Miranda FAN. Ações de controle da tuberculose: análise a partir do programa de melhoria do acesso e da qualidade da atenção básica. Texto Contexto Enferm. 2016;25(4):e4660015. DOI: http://dx.doi.org/10.1590/0104-07072016004660015

33. Zombini EV, Almeida CHD, Silva FPCV, Yamada ES, Komatsu NK, Figueiredo SM. Clinical and epidemiological profile of tuberculosis in childhood and adolescence. J Hum Growth Dev. 2013; 23(1):52-7. DOI: http://dx.doi.org/10.7322/jhgd.50391

34. Rodrigues ILA, Souza MJ. Representações sociais de clientes sobre a tuberculose: desvendar para melhor cuidar. Esc Anna Nery. 2005;9(1):80-7. 
35. Lafaiete RS, Silva CB, Oliveira MG, Motta MCS, Villa TCS. Investigação sobre o acesso ao tratamento de tuberculose em Itaboraí /RJ. Esc Anna Nery. 2011;15(1):47-53. DOI: http://dx.doi.org/10.1590/S1414-81452011000100007

36. Nogueira PA, Abrahão RMCM, Malucelli MIC. Baciloscopia de escarro em pacientes internados nos hospitais de tuberculose do Estado de São Paulo. Rev Bras Epidemiol. 2004; 7(1):54-63. DOI: http://dx.doi.org/10.1590/S1415-790X2004000100007

37. Lima LM, Harter J, Tomberg JO, Vieira DA, Antunes ML, Cardoszo-Gonzales RI. Avaliação do acompanhamento e desfecho de casos de tuberculose em município do sul do Brasil. Rev Gaúcha Enferm. 2016;37(1):e51467

38. Oliveira MF, Villa TCS. Acesso ao diagnóstico de tuberculose em serviços de saúde do município de Ribeirão Preto - São Paulo (2006-2007). Teste (Doutorado) - Enfermagem de Ribeirão Preto, Universidade de São Paulo: Ribeirão Preto: 2009.

39. Assis MMA, Silva EM, Silva CNL, Barbosa JF, Freitas MYGS, Cerqueira EM, et al. Avaliação do programa de controle de tuberculose em Feira de Santana/ BA (2007): limite e desafios. In: Villa TCS, Ruffino Netto A. Tuberculose: pesquisas operacionais. São Paulo: FUNCEP, 2009; p.165-75.

40. Mello DF, Vieira CS, Simpionato E, Biasoli-Alves ZMM, Nascimento LC. Genograma e Ecomapa: possibilidades de utilização na estratégia de saúde da família. Rev Bras Cresc Desenv Hum 2005;15(1):78-89. DOI: https://dx.doi.org/10.7322/jhgd.19751

41. Silva DM, Nogueira JA, Sá LD, Wysocki AD, Scatena LM, Villa TCS. Avaliação de desempenho de Serviços da Atenção Básica para o tratamento da tuberculose. Rev Esc Enferm USP. 2014;48(6):104453. DOI: https://doi.org/10.1590/S0080-623420140000700012

42. Queiroz EM, De-La-Torre-Ugarte-Guanilo MC, Ferreira KR, Bertolozzi MR. Tuberculosis: limitations and strengths of Directly Observed Treatment Short-Course. Rev Latino-Am Enfermagem. 2012;20(2):36977. DOI: http://dx.doi.org/10.1590/S0104-11692012000200021

43. Terra MF, Bertolozzi MR. Does directly observed treatment ("DOTS") contribute to tuberculosis treatment compliance? Rev Latino Am Enfermagem. 2008;16(4):659-64. DOI: http://dx.doi.org/10.1590/S010411692008000400002

44. Samico I, Hartz ZMA, Felisberto E, Carvalho EF. Atenção à saúde da criança: uma análise do grau de implantação e da satisfação de profissionais e usuários em dois municípios do estado de Pernambuco, Brasil. Rev Bras Saúde Mater Infant. 2005;5(2):229-40. DOI: http://dx.doi.org/10.1590/S151938292005000200012

45. Bezerra IMP. Translational medicine and its contribution to public. Health J Hum Growth Dev. 2017;27(1):6-9. DOI: http://dx.doi.org/10.7322/jhgd.127642

46. Alves SAA, Oliveira MLB. Sociocultural aspects of health and disease and their pragmatic impact. J Hum Growth Dev. 2018;28(2):183-8. DOI: http://dx.doi.org/10.7322/jhgd.147236 


\section{Resumo}

Introdução: A atenção básica é resultado do desenvolvimento e consolidação do SUS através do programa de Estratégia Saúde da Família. Diante do quadro de persistência da tuberculose em vários municípios do País, o Ministério da Saúde (MS) estabeleceu o Plano Nacional de Controle da Tuberculose (PNCT) cujas metas eram integrar $100 \%$ dos municípios brasileiros na luta contra a doença.

Objetivo: Avaliar o desempenho das ações e serviços de controle da tuberculose (TB) da Estratégia Saúde da Família no município de Salgueiro-PE.

Método: Trata-se de estudo transversal, quantitativo e descritivo de inquérito que avaliou serviços de saúde na cidade de Salgueiro-PE, envolvendo 40 participantes. Os dados foram coletados através de questionário com perguntas específicas para cada componente organizacional essencial da atenção básica para as ações de controle da TB, além de perguntas sobre o perfil do paciente, informações clínicas epidemiológicas e estado atual de saúde. A fim de conhecer as políticas realizadas no controle da TB no município em estudo, foi também elaborado um roteiro com perguntas direcionadas ao gestor.

Resultados: Houve predominância do sexo masculino com 28 (70\%), com ensino fundamental incompleto $15(37,5 \%)$ e com faixa etária de 34 a 59 anos de idade. Quanto ao local do diagnóstico, o hospital teve maior prevalência de casos diagnosticados com tuberculose com $62,5 \%$, os que realizavam tratamento supervisionado foram $85,0 \%$. As médias das ações avaliadas demonstraram que o município de Salgueiro-PE não desenvolve ações de educação em saúde e busca ativa de sintomáticos respiratórios, obtendo médias favoráveis apenas para realização da baciloscopia de diagnóstico, consultas mensais de controle e acompanhamento medicamentoso.

Conclusão: Houve fragilidades no desempenho das ações e serviços pela estratégia saúde da família no munícipio de Salgueiro, com prejuízos ao controle e ao tratamento, sendo necessário o fortalecimento das ações e serviços no combate à doença.

Palavras-chave: Tuberculose, atenção primária à saúde, avaliação dos serviços de saúde.

๑ The authors (2018), this article is distributed under the terms of the Creative Commons Attribution 4.0 International License (http:// creativecommons.org/licenses/by/4.0/), which permits unrestricted use, distribution, and reproduction in any medium, provided you give appropriate credit to the original author(s) and the source, provide a link to the Creative Commons license, and indicate if changes were made. The Creative Commons Public Domain Dedication waiver (http://creativecommons.org/publicdomain/zero/ $1.0 /)$ applies to the data made available in this article, unless otherwise stated. 